Türk Turizm Araştırmaları Dergisi
2019, 3(3): 471-483.
DOI: $10.26677 / T R 1010.2019 .173$

ARAȘTIRMA MAKALESI

\title{
Stajın Nasıl Geçti? Turizm Alanında Orta Öğretim Öğrencilerinin Staj Deneyimleri
}

Dr. Öğr. Üyesi Hakan SEZEREL, Anadolu Üniversitesi, Turizm Fakültesi, Turizm İşletmeciliği, Eskişehir, e-posta: hsezerel@gmail.com ORCID: https://orcid.org/0000-0003-1521-8638

Dr. Öğr. Üyesi Duran CANKÜL, Eskişehir Osmangazi Üniversitesi, Turizm Fakültesi, Gastronomi ve Mutfak Sanatları, Eskişehir, e-posta: durancankul@hotmail.com

ORCID: https://orcid.org/0000-0001-5067-6904

Öz

$\mathrm{Bu}$ araştırmanın amacı turizm lisesi öğrencilerinin staj kavramına yönelik metaforik algılarını belirlemektir. Söz konusu amaç doğrultusunda, araştırmada nitel araştırma yöntemine başvurulmuş ve betimleyici araştırma deseni benimsenmiştir. Veri toplama aracı olarak 2 adet açık uçlu sorudan oluşan anket formu kullanılmıştır. Araştırmanın çalışma grubunu Türkiye'de turizm eğitimi veren tüm liselerdeki 3. ve 4. sınıf öğrencileri oluşturmaktadır. Araştırma 20172018 eğitim-öğretim yılı güz dönemi boyunca uygulanmış ve turizm liselerinde öğrenim gören 292 öğrencinin katılımı ile gerçekleştirilmiştir. Araştırma sonuçlarına göre öğrenciler staj kavramını ifade etmek için 67 metafor üretmişlerdir. Öğrencilerin oluşturduğu metaforlar üç temada toplanmıştır. Bunlar; olumsuz, olumlu ve hem olumlu hem olumsuz algılardır. Araştırmada, öğrencilerin staj deneyimlerini ağırlıklı olarak olumsuz algıladıkları saptanmıştır. Söz konusu olumsuz metaforlar arasında "amelelik ve kölelik" öne çıan metaforlar olmuştur. Sonuç olarak öğrenciler kendileri için beceri, bilgi ve tutum değişimi yaratacağı düşünülen staj deneyimini ağırlıklı olarak kölelik ve amelelik ile ilişkilendirmiştir.

Anahtar Kelimeler: Turizm Eğitimi, Staj, Turizm Öğrencisi, Kölelik.

Makale Gönderme Tarihi: 03.05.2019

Makale Kabul Tarihi: 06.07.2019

\section{Önerilen Atıf:}

Sezerel, H. ve Cankül, D. (2019). Stajın Nasıl Geçti? Turizm Alanında Orta Öğretim Öğrencilerinin Staj Deneyimleri, Türk Turizm Araştırmaları Dergisi, 3(3): 471-483.

(C) 2019 Türk Turizm Araştırmaları Dergisi. 


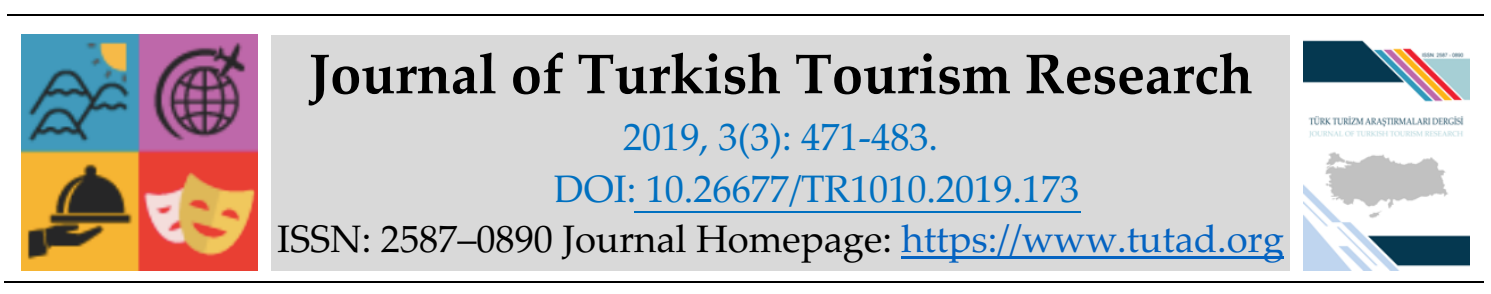

\title{
$\underline{\text { RESEARCH PAPER }}$
}

\section{How was the Internship? Internship Experience of Secondary Education Students in Tourism}

Assistant Prof. Dr. Hakan SEZEREL, Anadolu University, Faculty of Tourism, Eskişehir, e-mail: hsezerel@gmail.com ORCID: https://orcid.org/0000-0003-1521-8638

Assistant Prof. Dr. Duran CANKÜL, Eskişehir Osmangazi University, Faculty of Tourism, Eskişehir, e-mail: durancankul@hotmail.com

ORCID: https://orcid.org/0000-0001-5067-6904

\begin{abstract}
This study aims to depict the metaphorical perceptions of students in tourism vocational high schools. Accordingly, we benefited from the qualitative method and employed descriptive research model. The data were collected via an open-ended questionnaire consisted of two questions. The participants of the study are high school students 3rd and 4th grade in Turkey. The questionnaire was distributed to students through 2017- 2018 fall semester and the total sample was 292. The students generated 67 metaphors to Express training experience in total. The metaphors were classified in three themes. These are, namely, positive, negative, and mixed perceptions (perceptions work both ways). The study identified that the majority of the students perceive the training experience with negative qualities. The prominent metaphors were "construction work" and "slavery".
\end{abstract}

Keywords: Tourism Education, Internship, Tourism Student, Slavery.

Received: 03.05.2019

Accepted: 06.07.2019

\section{Suggested Citation:}

Sezerel, H. and Cankül, D. (2019). How was the Internship? Internship Experience of Secondary Education Students in Tourism, Journal of Turkish Tourism Research, 3(3): 471-483.

(C) 2019 Türk Turizm Araştırmaları Dergisi. 


\section{Gíriş}

Türkiye'de lisans düzeyinde turizm eğitimine yönelik zengin bir literatür bulunmaktadır. Bu literatür, daha çok nitelikli insan kaynağ 1 "yetiştirmeye" odaklanan ve bir anlamda yüzü sektörel beklentilere ve turizmin ekonomik kalkınmadaki rolüne dönük, pragmatik bir literatürdür (Sezerel ve Tonus, 2017). Eğitimden anlaşılan ise, genel olarak, işletmelerin beklentilerini karşılayan, nitelikli işgücü yetiştirme faaliyetidir (Emir vd., 2008; Solmaz ve Ulama, 2014:102). Bu durum yalnızca lisans eğitimi için geçerli olmayıp; nitelikli "ara eleman" yetiştirme prensibi ön lisans öğrencileri için de geçerli görünmektedir (Saçılık vd., 2016: 90). Orta öğretim için de aynı örüntüyü izlemek mümkündür. Nitekim Milli Eğitim Bakanlığı Eğitimi Araştırma ve Geliştirme Dairesi Başkanlığı; Anadolu Otelcilik ve Turizm Meslek Liselerine ilişkin yayınladığı raporda (MEB, 2006: 1), sektörün "üretim malzemesi" olan öğrencileri "kabullenmediğini" bunun nedeninin ise, (okullarda) sektörün istediği üretimin gerçekleşmediği, bu nedenle de sektörün ucuz işgücü temin etme yoluna gittiği belirtmektedir (MEB, 2006). Eğitimi düzenleyen resmi makamların görüşleri, akademik çalışmalarla koşut gitmektedir. Özetle, lisans, ön lisans ve orta öğretim kurumlarında turizm eğitiminin amacı, nitelikli "eleman" ve yönetici adayları yetiştirmektir.

Nitelikli işgücü yetiştirme hedefi, söz konusu öğretim kurumlarını; müfredat oluşturma, ders içeriklerinin hazırlanması ve okulun mimari yapısının tasarımında da çift yönlü bir amaca yönlendirmektedir. Bu amaç ise, teorik ve pratik (uygulamalı) eğitimin birbirini destekler nitelikte olmasıdır. Gelgelelim, turizm eğitimi ile ilgili tartışmalarda en çok ortaya konan sorun, teorik bilgiden ziyade, uygulama bilgisine dönük eksikliklerdir. Bunun üstesinden gelinmesi için yararlanılan başlıca kavram ise staj kavramıdır.

Türkiye'de zorunlu staj, turizm eğitimi sunan orta öğretim kurumlarında, önlisans ve lisans programlarında mesleki eğitimin bir parçası olarak görülmektedir. Staj; eğitimin "ayrılmaz bir parçası" olarak değerlendirilmekte (Akay vd., 2018: 232) ve olağan bir uygulama haline gelmektedir. Aynı doğrultuda, ortaöğretim kurumları için işletmelerde mesleki eğitim ve stajı düzenleyen yönetmelik (MEB, 2013) staj:

"İşletmelerde mesleki eğitime gönderilemeyen öğrencilerin diploma alabilmek için öğretim programlarıla kazandırılması öngörülen mesleki bilgi, beceri, tutum ve davranışların geliştirmeleri, sektörü tanımaları, iş hayatına uyumları, gerçek üretim ve hizmet ortamında yetişmeleri amacıyla işletmede yaptıkları toplam 40 iş günü süreli mesleki çalışma", olarak tanımlamaktadır. Tanımdan da anlaşılacağı gibi, kısa bir süre de olsa "gerçek" iş yaşamında bulunularak; bilgi, beceri, tutum ve davranışların iş yaşamının gereklerine uygun hale getirilmesi amaçlanmaktadır. Bu amaçların gerçekleşmesinin yegâne koşulu ise, öğrencilerin, eğitimleri sonunda turizm ve ilgili sektörlerde çalışmasıdır. Bununla birlikte, turizm stajlarının konaklama endüstrisinde kalma isteklerini nasıl etkilediğine ilişkin detaylı çalışmalar sınırlı görünmektedir (Chen ve Shen, 2012: 31).

Turizm öğrencilerinin turizm endüstrisine ilişkin tutumlarının bilinmesi gelecekte bu endüstride çalışıp çalışmayacaklarını tahmin etmede yardımcı olacağı düşünülmektedir (Kusluvan ve Kusluvan, 2000). Bu doğrultuda yerli ve yabancı literatürde yapılan çalışmalar, bu düşünceyi doğrular niteliktedir (Duman vd., 2006; Lam ve Ching, 2007; Köşker ve Unur, 2017; Farmaki, 2018). Lisans düzeyinde birinci sınıfa gelen öğrenciler ile mezuniyet aşamasındaki öğrencilerin turizm endüstrisine bakış açılarında, endüstriyle kurdukları ilişki önemli bir fark yaratmaktadır. Bu aşamada, stajlar önemli bir rol oynamaktadır (Kumar vd., 2014). Kimi araştırmalar (Emir vd., 2008; Mercan vd., 2015; Ulama vd., 2015) turizmde çalışma konusunda olumlu görüşleri örneklerken; kimi araştırmalar bu tutumların okula başlarken geliştirilen tutumlarla (Ikechukwu, 2017) ilişkilendirmektedir. 
Yapılan literatür incelemesinde, çok sayıda olmasa da lisans ve ön lisanstaki staj deneyimine ilişkin araştırmaların bulunduğu fakat ortaöğretim kurumlarında staj konusundaki çalışmaların sınırlı olduğu görülmüştür. Lisans ve önlisans düzeyindeki çalışmaların ise genellikle nicel araştırma modelini benimsediği, belirli illerle sınırlı kaldığı sonucuna varılmıştır. Bu nedenlerle, hem turizm ortaöğretim kurumlarında staj konusundaki literatüre katkıda bulunmak hem de öğrencilerin deneyimlerini kendi kavramlarıyla anlayabilmek amacıyla, bu çalışmada, turizm öğrenimi göre ortaöğretim kurumlarındaki öğrencilerin staja yönelik deneyimleri metafor analizleri yoluyla incelenmiştir. Araştırma soruları ise aşağıdaki gibidir:

1. Öğrenciler staj deneyimine ilişkin sahip oldukları algıları hangi metaforlar aracılığı ile açıklamaktadır?

2. Metaforlar hangi kategori ve temalarda sınıflandırılıp, açıklanabilir?

\section{LITERATÜR}

\section{Turizm, Çalışma ve Staj}

Turizmde çalışmanın temel, ayırt edici özellikleri bulunmaktadır. Tüzünkan (2018: 104) literatür taramasında bu özellikleri temel olarak; düşük ücretler, kötü çalışma koşulları, düzensiz ve uzun çalışma saatleri, sezonluk çalışma, yüksek işgücü devir oranı, düşük iş tatmini, motivasyon faktörlerinin eksikliği, iş güvenliğinin düşük olması, mesleki eğitimin yetersiz oluşu, mesleki imajın kötü olması, kariyer potansiyelinin düşük olması ve düşük statüde çalışma olarak sıralamaktadır. Nickson (2007: 5); aynı doğrultuda, turizm ve konaklama endüstrilerinde paradoksal olan bir duruma işaret ederek, çalışma koşullarının bir başka özelliğini göstermektedir. Buna göre; "doğası gereği", turizm ve konaklama işletmeciliğinde turistlerin algıladığ $\breve{1}$ hizmet kalitesini belirleyen en önemli unsurlardan biri, söz konusu işletmede turistle birebir ilişki kuran çalışanlardır. Öte yandan, en düşük statüde görülen bu işlerde, en düşük ücreti alan ve en eğitimsiz kişiler çalışmaktadır. Evrensel olan bu çalışma koşulları, Türkiye özelinde de varlığını sürdürmektedir.

Söz konusu çalışma koşulları, turizm eğitimi almanın anlamını sorgulanır hale getirmektedir. Nitekim, Duman vd., (2006: 52), ilgili alan literatüre dayanarak, turizm eğitimi alan kişilerin turizm sektöründe çalışmadığını ya da çalışmak istemedikleri sonucunu çıkartmaktadır. Bu isteksizliğin başında ise kariyer imkanlarının yetersizliği ya da öğrencilerin turizm sektöründe kariyer yapmaya yönelik olumsuz tutumları gelmektedir. Sektörde çalışmaya yönelik olumsuz tutumlar, işe alınma durumlarıyla da benzerlik göstermektedir. Sözgelimi, Lam ve Ching (2007) turizm öğrencilerinin turizm endüstrisinde işe alınma oranlarının düşüşte olduğunu belirtmektedir.

Bu çalışmada, staj konusu, işe alınma konusuyla ilişkili düşünülmektedir. Gerek turizmi müstakbel çalışanları olan öğrenciler için gerekse sektörde işverenler için staj önemli bir buluşma noktasıdır. Farmaki (2018) kariyer niyetleri ile staj deneyimleri arasındaki ilişkiyi incelediği çalışmasında, staj deneyiminin etkili olduğunu saptamıştır. Bunu destekleyen bir araştırmada, (Köşker ve Unur, 2017) öğrencilerin turizm sektöründe çalışma eğilimlerinin staj ve/veya mesleki deneyimle birlikte düştüğü, bir diğer deyişle, olumsuz çalışma koşullarının sektörde çalışmaya yönelik istekleri törpülediğini ifade etmektedir. Bu durum, lisans öğrencileri arasında meslekte kalma niyetleri açısından neredeyse yarı yarıyadır (Çatı ve Bilgin, 2013). Kusluvan ve Kusluvan (2000) turizm endüstrisinde çalışmanın farklı boyutlarına ilişkin olumsuz tutumları tespit etmiştir. Güzel (2010: 3420-21), öğrencilerin mesleğe yönelik tutumlarının olumsuz oluşunu, temel motivasyon ögelerinden yoksun olan çalışma ortamına bağlamaktadır. Ucuz iş gücü olarak 
görülme, sigortalarının yatmaması ile izin günlerinde çalıştıılmaya eşlik eden konaklama ve beslenme sorunları henüz mesleğin başında olumsuz tutumlar geliştirmektedir.

Tüzünkan (2018) Güney Kore'de lisans öğrencilerinin turizmde çalışmaya yönelik algılarını incelemiştir. Bu öğrenciler de bu araştırmanın katılımcılarına benzer biçimde, staj ya da kısa dönemli çalışmalar aracılığıyla turizmde çalışmıştır. Araştırma katılımcılarının turizm endüstrisi hakkında bilgi sahibi olduğunu ve turizm bölümlerini kendi istekleriyle seçtiklerini belirtmektedir. İşin yapısı, uzun çalışma saatlerinin aile hayatlarını olumsuz etkilediğini, ek olarak, başka insanlar tatil yaparken onlara hizmet etmenin "köleliğe" benzediğini dile getirmektedir. Öğrencilerin diğer çalışanları eğitimsiz olarak algıladığı ve kendilerinin eğitimli oldukları için kıskanıldıkları da ifade etmektedir. Bunun yanında, uzun ve düzensiz çalışma saatlerine göre alınan ücretin düşük olduğu rapor edilmiştir. Turizm işleri, ilginç, yapmaya değer, insanın beceri ve yeteneklerini kullanabileceği çalışırken zevk veren işler olmakla birlikte, sosyal kabulü düşük işlerdir. Öğrenciler, turizmde çalıştıklarını yakınlarına söylemekten imtina etmektedir.

Öte yandan, yerli literatürde; lisans düzeyindeki öğrencilerin turizm endüstrisi içinde çalışmayı düşündüğünü saptayan çalışmalar (Ulama vd., 2015) yer almaktadır. Yine tek fakülte kapsamında yapılan kimi araştırmalar (Mercan vd., 2015; Olcay vd., 2015) turizm stajlarının genel anlamda öğrenciler tarafından olumlu olarak algılandığını saptamaktadır.

Seyitoğlu ve Çakar (2017) eğitimcilerin öğrencilerin staj deneyimlerine daha fazla odaklanması gerektiğini belirtmekte ve metafor analizlerinin bu kapsamdaki önemine vurgu yapmaktadır. Yerli literatürde ise, Kalsen vd., (2017) mesleki ve teknik liseleri 12. Sınıfta okuyan öğrencilere yönelik gerçekleştirdikleri araştırmada metafor analizine başvurmuştur. Bir il sınırlılığında gerçekleştirilen araştırmanın bulguları, öğrencilerin staja yönelik genel olarak olumsuz bir değerlendirme yaptıkları ve ağırlıklı olarak "kölelik"le ilişkilendirdiklerini göstermektedir.

\section{YÖNTEM}

$\mathrm{Bu}$ çalışmada, nitel araştırma yöntemine başvurulmuş ve betimleyici araştırma deseni benimsenmiştir.

\section{Metafor Analizi}

Metaforlar, insanın dünyayı nasıl algıladığını, nesneler, olaylar ve hareketler hakkında ne düşündüklerini görme veya düşünme biçimi olarak ifade edilmektedir (Morgan, 1998). Son yıllarda kişilerin mesleklerine ilişkin algısal durumları ortaya çıkarmak amacıyla yaygın bir şekilde metafor analizi kullanılmaktadır. Miller (1987: 219) metaforların öğrencilerin belirli konular hakkında daha farklı düşünmelerini sağladığını, öğrenme sürecinde yararlı bir araç olduğunu, daha rahat ve fazla açıklama yapabildiklerini belirtmektedir. Bu doğrultuda çalışmada da öğrencilerin staj deneyimine ilişkin sahip oldukları algıları metaforlar aracılı̆̆ı ile açıklanmaya çalışılmıştır.

\section{Veri Toplama Aracı}

Araştırma 2017-2018 eğitim-öğretim yılı güz dönemi boyunca uygulanmıştır. Form elektronik ortamda hazırlanmıştır. Araştırmanın evrenini Türkiye' de turizm eğitimi veren tüm liselerdeki 3. ve 4. sınıf öğrencileri oluşturmaktadır. Her liseden bir hoca ile iletişime geçilerek öğrencilerine elektronik ortamda hazırlanan formu doldurtmaları sağlanmıştır. Araştırma turizm liselerinde öğrenim gören 292 öğrencinin katılımı ile gerçekleştirilmiştir. Araştırma verileri, Excel dosyası 
halinde elde edilmiş, kelime bulutu ve frekanslar için Nvivo 11 programından yararlanılmıştır. Öğrencilere gönderilen soru formu iki bölümden oluşmaktadır. Birinci bölüm, (yaş, cinsiyet, okul bilgisi, il bilgisi) demografik verilerden oluşmaktadır. İkinci bölümde ise üç soru sorulmuştur. Birinci soruda ve ikinci soruda boşluk doldurmaları istenmiştir: "Turizm sektöründe staj yapmak "..."benzer, Çünkü “...dır/dir". Son soruda ise isteğe bağlı açıklamaları sorulmuştur.

\section{Verilerin Analizi}

Verilerin analizinde Yıldırım ve Şimşek (2011) tarafından önerilen ve yerli literatürde (Hacıfazlığlu vd., 2011: 103-104; Çetinkaya, 2014: 140) başvurulan aşamalardan yararlanılmıştır:

A. Kodlama ve ayıklama: Araştırmacılar tarafından hazırlanan soru formu, web aracılığıyla okullardaki öğretmenlere gönderilmiş, öğretmenlerden alınan sözlü onaylardan sonra, öğrencilere okulda bilgisayar odasında doldurmaları için anket linki gönderilmiştir. Anketlerin doldurulmasınin ardından, otomatik olarak excel programına aktarılan veriler, metaforlar ve demografik veriler olarak ikiye ayrılmıştır. Metafor belirtmeyen ve eksik doldurulan formlar elenmiştir. Metaforlar A'dan Z'ye sıralanmıştır. Metaforların analizi sırasında benzerlik gösteren metaforlar bir araya toplanmıştır. Bu metaforlar Tablo 3, 4 ve 5'te belirtilmektedir. Kodlama ve ayıklama aşamasında veriler benzer kavramlar altında toplanmıştır. Örneğin; yenilik kodunda yeni doğmuş çocuk, yeni şeyler öğrenme, yeni bir şeyler keşfetme, yeni bir hayat birleştirildi. Toplantıda bulunma kültür ve kültür alışverişi birleştirilmiştir. Aktarılma ve farklı kültürlerle karşılaşma olduğu için. Hayat normal bir hayat birleştirildi. 2 okul metaforu öğrenmeyi gerekçe olarak gösterdiği için birleştirildi. Eş anlamlı sözcükler (deneyim, tecrübe) birleştirildi. yakın anlamdaki sözcükler birleştirildi (Pekiştirme, tekrar yapma). İşe benzemek, iş yapmaya benzemek, işe yaramak, iş yeri, iş öğrenmek, işleyiş personel olma, ucuz iş vb. Kat çıkma, zemin atma. İnşaat ile birleştirildi. Tiyatro kavramsal olarak doğaçlamalarla ilerlemediği halde katılımcının ifadesi olduğu gibi korundu. Katılımcıların ürettikleri metaforlar incelendiğinde; Katılımcıların ürettikleri metaforlar, metaforun konusu, kaynağı, kaynak ve konu arasındaki ilişki açısından incelenmiştir. Ancak veriler değerlendirilirken metafor belirtilmeyen, metafor belirtilmiş olsa da nedeni belirtilmeyen ve anlamsız metafor belirten 111 form elenerek araştırma kapsamı dışına bırakılmış ve analizler 181 öğrenciden toplanan formlar üzerinden gerçekleştirilmiştir. Elenen formların yüksek sayıda olması dikkate değerdir. Bu durum, tartışma bölümünde ele alınmaktadır. Öğrenciler tarafından üretilen metaforlar; gerekçeleri ve öğrenciler tarafından belirtilen görüşler ile birlikte değerlendirilerek bir temada toplanmıştır.

B. Sınıflandırma ve Kategori Geliştirme: Yukarıda söz edilen kodlama ve ayıklama aşamasının ardından araştırma amaçlarına daha iyi hizmet edeceği düşünülen bir sınıflandırmaya gidilmiştir. Buna göre, öğrencilerin staja yönelik kurdukları metaforlar; olumlu, olumsuz ve hem olumlu hem olumsuz olmak üzere üç gruba ayrılmıştır.

C. Güvenirlik: Bir üst kategoride öğrencilerin kurdukları metaforlar üç gruba ayrılmıştır. Çalışmada güvenilirliği sağlamak adına, oluşturulan bu üç grup altındaki metaforların, söz konusu grupları temsil edip etmediğini belirleyebilmek amacıyla uzman bir öğretim üyesinin görüşüne başvurulmuştur. Araştırmacıların geliştirdikleri gruplar ile uzman tarafından gerçekleştirilen eşleştirmeler karşılaştırılmıştır. Güvenilirlik hesaplaması Miles ve Huberman, (1994) önerdiği formüle göre; Güvenirlik = Görüş Birliği / (Görüş Birliği + Görüş Ayrılığı) hesaplanmıştır. Uzman, araştırmacılardan farklı olarak iki metaforu farklı bir gruba yerleştirmiştir. Bu doğrultuda ortalama güvenilirlik \%98 olarak 
bulunmuştur. Bu oran Miles ve Huberman (1994)'e göre güvenilir olarak kabul edilmektedir.

D. Verilerin gösterimi: Bu aşamada, elde edilen metaforlar, öncelikle kelime bulutuyla analiz edilmiş ve öne çıkan kavramlar sorgulanmıştır. Ardından, sınıflandırma ve kategori geliştirme aşamasında elde edilen bulgular, frekans ve yüzdeleriyle birlikte sunulmuştur.

\section{Araştırma Katılımcıları}

Araştırmaya katılan öğrencilerin \%61si lise $3 \% 39^{\prime}$ u lise 4 'te eğitim hayatına devam etmektedir. Öğrencilerin büyük çoğunluğu (\%83) stajlarını otel işletmelerinde yapmayı tercih etmiştir. \%15'i restoran işletmesinde \%2'si de seyahat acentesinde stajını tamamlamıştır.

Tablo 1. Demografik veriler

\begin{tabular}{|c|c|c|c|}
\hline Değişken & Gruplar & (n) & $(\%)$ \\
\hline \multirow{2}{*}{ Sinıf1 } & Lise 3 & 110 & 61 \\
\hline & Lise 4 & 71 & 39 \\
\hline \multirow{3}{*}{$\begin{array}{l}\text { Çalıştı̆̆1 } \\
\text { Türü }\end{array}$} & Otel & 150 & 83 \\
\hline & Restoran & 27 & 15 \\
\hline & Seyahat Acentesi & 4 & 2 \\
\hline \multirow{7}{*}{ Çalıştığı Departman } & $\begin{array}{l}\text { F\&B departmanı ve Restoran (Servis, Bar, } \\
\text { Mutfak) }\end{array}$ & 107 & 59 \\
\hline & Kat Hizmetleri & 38 & 21 \\
\hline & Ön büro & 27 & 15 \\
\hline & Seyahat Acentesi (Operasyon) & 3 & 2 \\
\hline & Müşteri İlişkileri & 2 & 1 \\
\hline & Güvenlik & 2 & 1 \\
\hline & Teknik Servis & 2 & 1 \\
\hline \multirow{6}{*}{ Staj Yaptığı İl } & Antalya & 84 & 46,3 \\
\hline & Muğla & 21 & 11,6 \\
\hline & Aydın & 21 & 11,6 \\
\hline & İzmir & 15 & 8,8 \\
\hline & İstanbul & 10 & 5,4 \\
\hline & Diğer İller & 30 & 16,3 \\
\hline
\end{tabular}

Öğrencilerin stajlarını yaptıkları departmanlara bakıldığında yarısından fazlasının (\%59) yiyecek içecekle ilgili departmanları, \%21'inin kat hizmetleri, \%15'inin ön büro departmanını tercih ettiği görülmektedir. Öğrencilerin staj yaptıkları illerin büyük çoğunluğu Akdeniz ve Ege bölgesinde yer almaktadır. En fazla tercih edilen il \%46,3 ile Antalya daha sonra \%11,6 ile Muğla ve Aydın takip etmektedir.

\section{Kelime Bulutu}

Elde edilen veri setinde, en fazla sayıda hangi sözcüklerin bulunduğunu saptayabilmek için kelime bulutu analizi yapılmıştır. Tablo 2' de kelime bulutundan çıkan sonuçlar gösterilmektedir. 
Tablo 2. Öğrencilerin Staj Algıları ile ilgili Öne Çıkan Metaforları

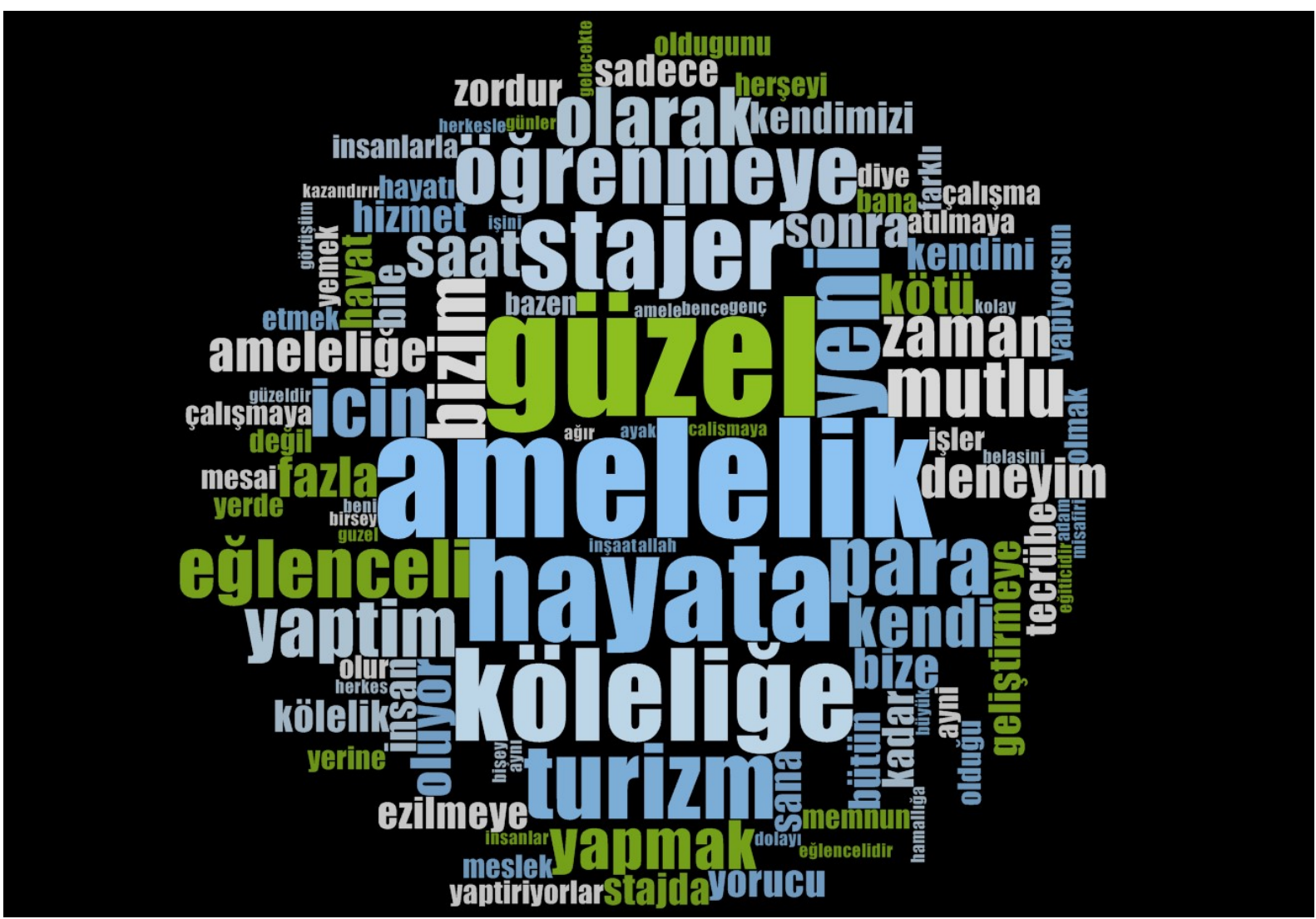

Kelime bulutu analizinde, "gibi" "çünkü" "için" "çok" "daha" veri setinden çıkarılmıştır. Staj deneyimlerini tanımlayan sözcükler; amelelik (n: 24), kölelik (n: 18), iş (13), hayat (13) ve öğrenme (n: 10) olarak öne çıkmaktadır.

Kelime bulutunda elde edilen genel bakışla tüm sözcüklerin frekanslarına bakılmış ve veriler araştırmacılar tarafından ayrı ayrı kodlanmıştır. Elde edilen kodların staja ilişkin algılarının yönelik olumlu, olumsuz ve hem olumlu hem de olumsuz olarak değerlendirilebilecek anlamlar taşıdığı konusunda fikir birliğine varılmıştır. Buna göre, öğrencilerin verdikleri yanıtlar üç temada toplanmaktadır. Bunlar; olumlu, olumsuz ve hem olumlu hem olumsuz olarak adlandırılmıştır.

Olumlu algılarda; öğrenme kodu öne çıkmaktadır. Olumlu algılar altında en çok öğrenme kodunun ifade edilmesi, stajın eğitsel hedefleri düşünüldüğünde iyimser bir sonuç ortaya koymaktadır. Öğrenmeye eşlik eden ve yine staj yapmanın hedeflerine uygun olan; pişmek, hazırlık, inşaat, kelebek lavrası, maraton, gelişim, keşif ve uzay kodları öğrencilerin stajlarda istendik bir algı geliştirdiklerini göstermektedir. Diğer bir deyişle; bilgi, beceri ve tutum değiştirme amaçlarıyla uyumlu bir staj deneyimi geçirdiklerini göstermektedir. Buna ek olarak; öğrencilerin belirttikleri, eğlence, dans, rüzgar ve su gibi kodlar, staj deneyiminin duyuşsal alanda da olumlu olarak algılandığını göstermektedir. 
Tablo 3. Öğrencilerin Staj Algılarına Yönelik Geliştirdikleri Olumlu Metaforlar

\begin{tabular}{cllrrlll}
\hline $\begin{array}{c}\text { Metafor } \\
\text { No }\end{array}$ & Metafor Ad1 & $\mathbf{( n )}$ & $\begin{array}{c}\mathbf{( \% )} \\
\text { Metafor } \\
\text { No }\end{array}$ & $\begin{array}{c}\text { Metafor Ad1 } \\
\text { (n) }\end{array}$ & $\mathbf{( \% )}$ \\
\hline 1. & Aile & $\mathbf{1}$ & $\mathbf{1 , 9}$ & 14 & Kültür & $\mathbf{4}$ & $\mathbf{7 , 5}$ \\
\hline 2. & Ö̆ğrenme & $\mathbf{1 0}$ & $\mathbf{1 8 , 9}$ & 15 & Maraton & $\mathbf{1}$ & $\mathbf{1 , 9}$ \\
\hline 3. & Şans & $\mathbf{1}$ & $\mathbf{1 , 9}$ & 16 & Mutluluk & $\mathbf{3}$ & $\mathbf{5 , 7}$ \\
\hline 4. & Dans & $\mathbf{1}$ & $\mathbf{1 , 9}$ & 17 & Hazırlı & $\mathbf{2}$ & $\mathbf{3 , 8}$ \\
\hline 5. & Disiplin & $\mathbf{1}$ & $\mathbf{1 , 9}$ & 18 & Pişmek & $\mathbf{1}$ & $\mathbf{1 , 9}$ \\
\hline 6. & Eğlence & $\mathbf{5}$ & $\mathbf{9 , 4}$ & 19 & Rüzgar & $\mathbf{1}$ & $\mathbf{1 , 9}$ \\
\hline 7. & Misafir & $\mathbf{1}$ & $\mathbf{1 , 9}$ & 20 & Su & $\mathbf{1}$ & $\mathbf{1 , 9}$ \\
\hline 8. & Gezi & $\mathbf{2}$ & $\mathbf{3 , 8}$ & 21 & Tatil & $\mathbf{1}$ & $\mathbf{1 , 9}$ \\
\hline 9. & Güzel (lik) & $\mathbf{4}$ & $\mathbf{7 , 5}$ & 22 & Ressam & $\mathbf{1}$ & $\mathbf{1 , 9}$ \\
\hline 10. & İnşaat & $\mathbf{2}$ & $\mathbf{3 , 8}$ & 23 & Ustalaşmak & $\mathbf{1}$ & $\mathbf{1 , 9}$ \\
\hline 11. & Karınca & $\mathbf{1}$ & $\mathbf{1 , 9}$ & 24 & Uzay & $\mathbf{1}$ & $\mathbf{1 , 9}$ \\
\hline 12. & Kelebek lavrasi & $\mathbf{1}$ & $\mathbf{1 , 9}$ & 25 & Vücut & $\mathbf{1}$ & $\mathbf{1 , 9}$ \\
\hline 13. & Gelişim & $\mathbf{4}$ & $\mathbf{7 , 5}$ & 26 & Keşif & $\mathbf{1}$ & $\mathbf{1 , 9}$ \\
\hline & & & & & Toplam & $\mathbf{5 3}$ & \\
\hline
\end{tabular}

Tablo 4. Öğrencilerin Staj Algılarına Yönelik Geliştirdikleri Olumsuz Metaforlar

\begin{tabular}{|c|c|c|c|c|c|c|c|}
\hline $\begin{array}{c}\text { Metafor } \\
\text { No }\end{array}$ & Metafor Adı & (n) & $(\%)$ & $\begin{array}{c}\text { Metafor } \\
\text { No }\end{array}$ & Metafor Adı & (n) & $(\%)$ \\
\hline 1. & Amelelik & 24 & 29,6 & 13 & İkiyüzlülük & 1 & 1,2 \\
\hline 2. & Bencillik & 1 & 1,2 & 14 & Kölelik & 18 & 22,2 \\
\hline 3. & Yük & 1 & 1,2 & 15 & Hatıra & 1 & 1,2 \\
\hline 4. & Sorumluluk & 1 & 1,2 & 16 & Ölüm & 5 & 6,2 \\
\hline 5. & İşkence & 4 & 4,9 & 17 & Oyuncak & 1 & 1,2 \\
\hline 6. & Çıraklık & 1 & 1,2 & 18 & Rezillik & 1 & 1,2 \\
\hline 7. & Evlatlık & 1 & 1,2 & 19 & Salaklık & 1 & 1,2 \\
\hline 8. & Eziyet & 6 & 7,4 & 20 & Saygısızlık & 2 & 2,5 \\
\hline 9. & Haksızlık & 1 & 1,2 & 21 & Yaprak & 1 & 1,2 \\
\hline 10. & Hamallık & 3 & 3,7 & 22 & Daliş & 1 & 1,2 \\
\hline 11. & Hapishane & 1 & 1,2 & 23 & Zindan & 3 & 3,7 \\
\hline \multirow[t]{2}{*}{12.} & Hiçlik & 1 & 1,2 & 24 & Zulüm & 1 & 1,2 \\
\hline & & & & & Toplam & 81 & \\
\hline
\end{tabular}

Çalışmada elde edilen ikinci başlık, olumsuz algılardır. Bu başlıkta ifade edilen kodlardan amelelik ve kölelik kodları olumsuz algıya dönük kodların yarısını oluşturmaktadır. Öğrenciler bu kodlara ek olarak; haksızlık, oyuncak-mış gibi muamele görmek, sözlü ve sözsüz saygısızlık davranışlarını algılamaktadır. Amelelik ve kölelik metaforlarının ardından vurgulanan çarpıcı metaforlar ise; ölüm, işkence ve eziyet kodlarıdır. Bu kodlar; stajların öğrencileri iş yaşamına hazırlamak ve öğrenme amaçlarından uzaklaştığını göstermektedir. Ayrıca, bu kodlar, staj yaşantısının öğrencileri meslekten uzaklaştıran ve öğrencilerin bilişsel, duyuşsal ve psikomotor gelişimlerini engelleyen yanlarına dikkat çekmektedir. 
Tablo 5. Öğrencilerin Staj Algılarına Yönelik Geliştirdikleri Hem Olumlu Hem Olumsuz Metaforlar

\begin{tabular}{cllrrlrr}
\hline $\begin{array}{c}\text { Metafor } \\
\text { No }\end{array}$ & Metafor Adi & (n) & $\mathbf{( \% )}$ & $\begin{array}{c}\text { Metafor } \\
\text { No }\end{array}$ & Metafor Ad1 & (n) & (\%) \\
\hline 1. & Askerlik & $\mathbf{3}$ & $\mathbf{6 , 4}$ & 10 & Mum & $\mathbf{1}$ & $\mathbf{2 , 1}$ \\
\hline 2. & İş & $\mathbf{1 3}$ & $\mathbf{2 7 , 7}$ & 11 & Paragraf & $\mathbf{1}$ & $\mathbf{2 , 1}$ \\
\hline 3. & Denge bozukluğu & $\mathbf{1}$ & $\mathbf{2 , 1}$ & 12 & Pekiştirme & $\mathbf{2}$ & $\mathbf{4 , 3}$ \\
\hline 4. & Futbol oynamak & $\mathbf{1}$ & $\mathbf{2 , 1}$ & 13 & Sabır & $\mathbf{1}$ & $\mathbf{2 , 1}$ \\
\hline 5. & $\begin{array}{l}\text { Deneyim } \\
\text { tecrübe) }\end{array}$ & $\mathbf{3}$ & $\mathbf{6 , 4}$ & 14 & Şekersiz Çay & $\mathbf{1}$ & $\mathbf{2 , 1}$ \\
\hline 6. & Gökyüzü & $\mathbf{2}$ & $\mathbf{4 , 3}$ & 15 & Zor (luk) & $\mathbf{1}$ & $\mathbf{2 , 1}$ \\
\hline 7. & Hayat & $\mathbf{1 3}$ & $\mathbf{2 7 , 7}$ & 16 & Sikıc (hayat) & $\mathbf{1}$ & $\mathbf{2 , 1}$ \\
\hline 8. & His & $\mathbf{1}$ & $\mathbf{2 , 1}$ & 17 & Tiyatro (drama) & $\mathbf{1}$ & $\mathbf{2 , 1}$ \\
\hline 9. & Kitap & $\mathbf{1}$ & $\mathbf{2 , 1}$ & & Toplam & $\mathbf{4 7}$ & \\
\hline
\end{tabular}

Üçüncü başlık ise, iki yönlü düşünülebilecek olan kodlardır. Burada öne çıkan iki temel kod ise iş ve hayattır. Öğrencilerin ürettikleri metaforları açıklarken kullandıkları "çünkü........" ifadeleri ile metaforlara yönelik yazdıkları açıklamalar, olumlu ve olumsuz algıları birlikte sunmaktadır. Stajın geçiciliği ve iş yaşamıyla ilişkisi, bu metaforların ortaya çıkışındaki temel unsur olarak görülmektedir.

\section{TARTIŞMA VE SONUÇ}

$\mathrm{Bu}$ araştırma, orta öğretim kurumlarında turizme yönelik staj ile ilgili öğrenci algılarını sunmaktadır. Araştırmanın turizm eğitimi alanında ortaöğretim düzeyinde birden fazla ile metafor analizi yoluyla öğrenci görüşlerini sunan ilk çalışmalardan biri olması nedeniyle kuramsal; elde ettiği verilerle politika yapıcılara öneriler sunması açısından ise uygulamaya katkı sunacağı umulmaktadır. Araştırmada elde edilen metaforlara ilişkin üç tema belirlenmiştir. Bunlar; olumsuz, olumlu ve hem olumlu hem olumsuz algilardır.

İlk tema olumsuz algılardır. Araştırmada, öğrencilerin staj deneyimlerini ağırlıklı olarak olumsuz algıladıkları saptanmıştır. Öğrencilerin ürettikleri metaforlar staj sürecinin istendik sonuçlarından ayrıştığını göstermektedir. Elde edilen metaforlar ve öğrencilerin yaptıkları açıklamalar; öğrencilerin staj deneyimini otellerde "background" çalışması ile sınırlı yaşadığını ortaya koymaktadır. Bu durum, mevcut otelcilik işgücüyle koşutluk göstermektedir. Bu nedenle, turizm stajlarının eğitim yönünün sektörün temel sorunlarına benzer biçimde zayıf olduğu görülmektedir (Poulston, 2008). Oysaki stajlar, tanımları gereği öğrencilerde bilgi ve beceri arttırma için eğitim kurumları tarafından zorunlu kılınan süreçlerdir. Bu açıdan bakıldığında, stajların istenen ya da beklenen etkiyi sağlamadığı görülmektedir. Öğrencilerin ürettikleri toplam 181 metaforun yarısına yakınının (81) olumsuz oluşu dikkate değerdir. Öğrenciler kendileri için beceri, bilgi ve tutum değişimi yaratacağı düşünülen staj deneyimini ağırlıklı olarak kölelik ile ilişkilendirmektedir. Kölelik teması Tüzünkan (2018) çalışmasını teyit etmektedir. İnsanların tatil yaptığ 1 bir mekanda onlara hizmet etmek, Güney Koreli öğrenciler tarafından da "kölelik" olarak algılanmaktadır. Kalsen vd., (2014) çalışmasında da kölelik metaforu öne çıkan bir metafor olmuştur. Öğrencilerin staj deneyiminden istedikleri ölçüde yararlanamadıkları da not edilmektedir. Örneğin, yabancı dillerini geliştirme beklentisinin gerçekleşmemesi, yaptıkları işlerle ilgili önerilerinin dikkate alınmaması ve örgütsel adalet algılarının düşük olması bu algının nedenlerindendir (Akay vd., 2018). 
İkinci grup metaforlar ise stajın olumlu yönlerini vurgulamaktadır. Bu grup içinde yer alan gökyüzü benzetmesi olumlu bakışı özetlemektedir: "Staj, gökyüzüne benzer çünkü birçok deneyim vardır ve ne ile karşılaşacă̆ımızı bilemeyiz". Yapılan stajın mezuniyet sonrası iş yaşamlarında başarılı olmalarında katkı sağlayacağını, mesleki açıdan kendilerine olan güvenlerini arttırdığını, iş yaşamlarını tanımalarında yardımcı olduğunu da belirtmişlerdir. Staj süresince sosyal ve beşeri ilişkiler hususunda tecrübe kazandıklarını, iş bulma imkânını arttıracağını düşündüklerini, staj eğitiminin yeni bilgi ve beceriler kazandırdığını, iş disiplini ve iş ahlakı kazandıklarını belirtmişlerdir. İşletmenin lojman kapasitesinin yeterli olmadığını, haftalık izinlerin düzenli verildiğini, stajdan sonra bu sektörde tekrar çalışmayı istediklerini ortaya koymaktadır (Akay vd., 2018).

Üçüncü grup metaforlarda ise hem olumlu hem de olumsuz yönleri öne çıkmaktadır. Bu grubu en iyi özetleyen metaforlardan biri aşktır. Bir öğrenci staj sürecini aşka benzeterek, duygularınızı iyi ya da kötü etkileyen bir süreç olarak tanımlamaktadır. Bu gruptaki metaforlar öğrencilerin metaforlarla iki yönlü (ambivalent) bir ilişki kurduğunu göstermektedir. Staj süreci zorluklara sahiptir ama öte yandan geliştiricidir. Staj sonrası öğrencilerin eğitim aldıkları bölüme olan ilgileri ile turizmde çalışmaya yönelik bakış açılarında olumlu gelişmeler olduğu, işletmelerin işi öğrenmelerinde bilgi ve beceri kazanmalarında gerekli ortamı hazırlama konusunda etkili konularında kararsız oldukları ortaya çıkmaktadır (Akay vd., 2018).

Bu çalışmada literatür taraması ve görgül bulgulardan elde edilen sonuçlardan birisi de staj ve mesleki eğitim konusunda başlıca paydaş olmasına karşın, öğrenci görüş ve deneyimlerinin göz ardı edilmesidir. Staj programlarının yapılandırılmasında, bu konudan birincil olarak etkilenen ve süreci bizzat deneyimleyen öğrencilerin stajların planlanmasında ve politikaların oluşturulmasında daha fazla söz sahibi olmaları gerektiği ortaya çımmaktadır. Bunun iki önemli gerekçesi bulunmaktadır. Birincisi, etik açıdan bir bireyin üstelik henüz yetişkinliğe geçmeden ve zorunlu olarak staj programına alınması olağan değil, tartışmalı bir durumdur. Bu nedenle, işgücü konumunda görülerek kötü koşullarda ve eğitimden yoksun olarak işletmelerde zaman geçirmeleri pedagojik olarak da tartışmayı hak etmektedir. İkincisi, çalışmanın başında belirtildiği gibi yönetimci ya da işletmeci bakış açısıyla da sorunludur. Bunun nedeni, turizm işletmelerinde stratejik olarak fark yaratan en önemli unsurun insan kaynağ 1 olmasıdır. Potansiyel beşeri sermaye henüz orta öğretim aşamasında bir iş kolundan uzaklaşmaktadır.

Mesleğe yönelik olumsuz tutumların giderilmesi için literatürde sıralanan pek çok öneri bulunmaktadır. Lam ve Ching (2007) konaklama işletmeciliğinde staja yönelik gerçekleştirdikleri araştırmada, takım çalışması ve katılımcılık ile özerklik ve danışman desteğinin staja yönelik tatmini etkilediğini saptamıştır. Bu nedenle, stajlarda, öğrencilerin daha fazla bireysel inisiyatif kullanabileceği çalışma ortamının hazırlanması ya da bunun bir çalışma ortamı olduğu kadar bir eğitim ortamı olduğunun da akıldan çıkarılmaması gerekmektedir. Güzel (2010), öğrencilerin işyerinde diğer çalışanlarla aynı işleri yapmalarına karşın daha düşük ücret almalarını ve aldıkları eğitimi işyerinde uygulamamalarını sorun olarak görmekte ve motivasyona ilişkin temel problemlerin ortadan kaldırılmasının mesleğe yönelik olumlu tutumlara neden olabileceğini belirtmektedir.

Hemen tüm araştırmalarda olduğu gibi, bu araştırmanın da bazı sınırlılıkları bulunmaktadır. Bunlardan birincisi, her ne kadar metafor çalışması, katılımcıların görüşlerini rahat ve özgür biçimde ortaya koymalarını sağlasa da metafor çalışmasına katılım, bir aşinalık gerektirmektedir. Öncelikle gerek ortaöğretimde veri toplamının güçlüğü ve ilgili literatürün sınırlılığı bu çalışmanın araştırmacılarını metafor analizi ile bir başlangıç yapmaya teşvik etmiştir.

İlerleyen çalışmalarda, öğrencilerle yapılacak görüşmeler, ortaöğretim kurumlarında turizm alanına ilişkin bir ölçek hazırlanması ve hem nitel hem de nicel araştırma yöntemlerinin bir arada 
işe koşulmasının daha kapsamlı bilgi sunacağı düşünülmektedir. Bunun yanında, elde edilen metaforların hem ülke içinde hem de yurtdışında kültürel karşılaştırmalar yapılmasının yararlı olacağı görülmektedir. Böylece turizm alanında staj yapmaya yönelik bilgi birikimine daha fazla katkı yapılabileceği düşünülmektedir.

\section{KAYNAKÇA}

Akay, B., Uslu, A. ve Sancar, M. F. (2018). Turizm Eğitimi Alan Öğrencilerin Staj Döneminde Yaşadıkları Sorunlar: Lisans ve Ortaöğretim Turizm Öğrencileri Örneği. OPUS - Uluslararası Toplum Araştırmaları Dergisi, 8 (Gençlik Araştırmaları Özel Sayısı), 212-236.

Chen, T. L. and Shen, C. C. (2012). Today's intern, tomorrow's practitioner? -The influence of internship programmes on students' career development in the Hospitality Industry. Journal of Hospitality, Leisure, Sport \& Tourism Education, 11(1), 29-40.

Çatı, K. ve Bilgin, Y. (2013). Turizm Lisans Öğrencilerinin Turizm Sektöründe Çalışma Eğilimleri. C.Ü. İktisadi ve İdari Bilimler Dergisi, (14) 1, 23-45.

Çetinkaya, S. (2014). Öğrencilerinin Kendi Mesleklerine İlişkin Algılarının Metafor Analizi ile İncelenmesi, Pamukkale Üniversitesi Ĕ̆itim Fakültesi Dergisi, 36(2), 137-150.

Duman, T., Tepeci, M. ve Unur, K. (2006). Mersin'de Yükseköğretim ve Orta Öğretim Düzeyinde Turizm Eğitimi Almakta Olan Öğrencilerin Sektörün Çalışma Koşullarını Algılamaları ve Sektörde Çalışma İsteklerinin Karşılaştırmalı Analizi. Anatolia: Turizm Araştırmaları Dergisi, 17(1), 51-69.

Emir, O., Arslan, S. ve Kılıçkaya, Ş. (2008). Turizm İşletmeciliği ve Otelcilik Programı Öğrencilerinin Staj Uygulamaları Hakkındaki Görüşlerinin Değerlendirilmesi: Afyon Kocatepe Üniversitesi Örneği. Akü İktisadi ve İdari Bilimler Dergisi, 10 (2), 273-291.

Farmaki, A. (2018). Tourism and Hospitality Internships: A Prologue to Career Intentions? Journal of Hospitality, Leisure, Sport \& Tourism Education, 23, 50-58.

Güzel, F. Ö. (2010). Turizm Öğrencilerinin Staj Döneminde Edindikleri Motivasyonun Herzberg Teorisine Göre Değerlendirilmesine Yönelik Bir Araştırma. Journal of Yaşar University, 5(20), 34153429.

Hacıfazlıŏlu, Ö., Karadeniz, Ş. ve Dalgıç, G. (2011). Okul yöneticilerinin teknoloji liderliğine ilişkin algıları: metafor analizi örneği. Eğitim Bilimleri Araştırmaları Dergisi-Journal of Educational Sciences Research, 1(1).

Ikechukwu, O., Mumsy E. C. and Tshinakaho N. (2017). Student Profile and Perceptions of Hospitality Management Education: Universities in South Africa, African Journal of Hospitality, Tourism and Leisure, 6 (3), 1-12.

Kalsen, C., Kaplan, İ. ve Şimşek, M. (2017). Mesleki ve Teknik Liseleri 12. Sınıf Öğrencilerinin İşletmelerde Yaptıkları Staj ve Beceri Eğitimi Çalışmalarına İlişkin Algıları, Journal of Human Sciences, 14(3), 3044-3060.

Köşker, H. ve Unur, K. (2017). Turizm Lisans Öğrencilerinin Turizm Sektöründe Çalışma Eğilimleri Üzerine Bir Araştırma. Seyahat ve Otel İşletmeciliği Dergisi, 14(2), 126-141.

Kumar, A. (2015). Changing Perception of Students toward Hospitality Industry: A Comparative Analysis. International Journal of Tourism \& Hospitality Reviews, 1(1), 07-12. 
Kusluvan, S. and Kusluvan, Z. (2000). Perceptions and attitudes of undergraduate tourism students towards working in the tourism industry in Turkey. Tourism Management, 21(3), 251-269.

Lam, T. and Ching, L. (2007). An exploratory study of an internship program: The case of Hong Kong students. International Journal of Hospitality Management, 26(2), 336-351.

MEB. (2006). Anadolu Otelcilik ve Turizm Meslek Liselerinin Mevcut Durumları ve Açılmalarına Zemin Oluşturacak Kriterlerin Belirlenmesi. https://www.meb.gov.tr/earged/earged/AOTML_Mevcut_Durumlari.pdf. (Erişim Tarihi: 10 Mart 2019)

MEB. (2013). Millî Eğitim Bakanlığı Ortaöğretim Kurumları Yönetmeliği http://www.resmigazete.gov.tr/eskiler/2013/09/20130907-4.htm. (Erişim Tarihi: 10 Mart 2019)

Mercan, Ș. O., Aksu, M., Yıldırım, H. M. and Bucak, T. (2015). Perception of internship on students studying in the field of tourism at undergraduate level: a research at Çanakkale Onsekiz Mart University. Journal of Academic Social Science Studies, (32), 319-333.

Miles, M. B. and Huberman A. M. (1994). An Expanded Source Book: Qualitative Data Analysis, London: Sage Publications.

Miller, I. S. (1987). Some Comments on The Utility of Metaphors for Educational Theory and Practice. Educational Theory, 37(3).

Morgan, G. (1998). Yönetim ve Örgüt Teorilerinde Metafor, Mess Yayınları, İstanbul.

Nickson, D. (2007). Human resource management for hospitality, tourism and events. Routledge.

Olcay, A., Yıldırım, İ. ve Sürme, M. (2015). Turizm Eğitimi Alan Öğrencilerin Staj Eğitimi Hakkında Görüşleri: Gaziantep İli Örneği, Journal of Higher Education \& Science/Yüksekögretim ve Bilim Dergisi, 5(3).

Poulston, J. (2008). Hospitality workplace problems and poor training: a close relationship. International Journal of Contemporary Hospitality Management, 20(4), 412-427.

Saçllk, M. Y., Çevik, S. ve Özkan, Ç. (2016). Turizm ve Otel İşletmeciliği Bölümü Önlisans Öğrencilerinin "Turizm" Olgusuna İlişkin Metaforik Algıları, Akademik Bakış Dergisi, 53, 85-103.

Seyitoğlu, F. ve Çakar, K. (2017) Tourism Education and Internships: A Metaphor Analysis, Journal of Teaching in Travel \& Tourism, 17:4, 269-280.

Sezerel, H. ve Tonus, Z. (2017). Turizm Fakültelerinin Gözünden Eğitime Bakış, Selçuk Üniversitesi Sosyal Bilimler Enstitüsü Dergisi, 38, 112-121.

Solmaz, S. A. ve Ulama,S. (2014). Türkiye'de Turizm Eğitim-Öğretiminde Mevcut Durum Üzerine Analitik Bir Değerlendirme, Ist International Congress of Tourism \& Management Researches, 97-115.

Tuzunkan, D. (2018). Undergraduate Tourism Students' Perceptions and Attitudes Towards Tourism Industry: The Case of Daejeon, South Korea. GeoJournal of Tourism and Geosites, 21, 103111.

Ulama, Ş., Batman, O. ve Ulama, H. (2015). Lisans Düzeyinde Turizm Eğitimi Alan Öğrencilerin Kariyer Algılamalarına Yönelik Bir Araştırma: Sakarya Üniversitesi Örneği, Bartın Üniversitesi I.I.̇.F. Dergisi, 6 (12), 339-366.

Yıldırım, A. ve Şimşek, H. (2011). Sosyal bilimlerde nitel araştırma yöntemleri. (8. Basım). Ankara: Seçkin Yayıncılık. 